\title{
Total Phosphorus Loading onto the Water Environment from Common Carp Fed Commercial Diets
}

\author{
Takeshi Watanabe, Parveen Jahan, Shuichi Satoh, and Viswanath Kiron
}

Laboratory of Fish Nutrition, Department of Aquatic Bioscience, Tokyo University of Fisheries, Minato, Tokyo 108-8477, Japan.

(Received January 20, 1999)

\begin{abstract}
The recent status of total phosphorus loading (T-P) from carp culture was evaluated by feeding fingerling carp (average weight $12.4 \pm 0.4 \mathrm{~g}$, duplicate tanks, 4 weeks at $23-25^{\circ} \mathrm{C}$ ) six commercial diets used in Lake Kasumigaura (Ibaragi Prefecture, Japan) during 1996. The T-P was determined by employing three methods based on 1) water extractable phosphorus $(\mathrm{P}), 2) \mathrm{P}$ absorption, and 3) $\mathrm{P}$ retention. The total $P$ contents of six diets ranged from 1.07 to $2.09 \%$ and the absorption rates were 26.9 to $37.3 \%$, being close to the amount of $P$ extracted with deionized water. Growth performances were markedly different and generally high in fish fed diets containing $0.6-0.8 \%$ available $\mathrm{P}$. The values for $\mathrm{T}-\mathrm{P}$ between those calculated based on the water extractable $\mathbf{P}$ and absorption rates of dietary $\mathbf{P}$ were nearly identical whereas the values based on retention were slightly higher. The difference between the total amount of $P$ given to fish and the amount of $P$ retained in fish body can be regarded as T-P onto the environment. Therefore, the rate of $P$ retention should be employed in the practical estimation of T-P from carp culture operation. The T-P (based on retention) varied greatly between the diets and ranged from 9.1 to $18.8 \mathrm{~kg} / \mathrm{t}$ carp production (13.6 on average) among the diet groups. A high lipid content was observed in the whole body of fish fed diets with low amounts of available $P$ as a typical $P$ deficiency symptom.
\end{abstract}

Key words: carp culture, available phosphorus, phosphorus retention, phosphorus discharge.

Any type of intensive fish culture operation always leads to release into the environmental water of both organic and inorganic nutrients through branchial and urinary or fecal loss together with feed wastes. The organic nutrients cause oxygen deficit conditions while inorganic compounds such as phosphate and ammonia lead to eutrophication." Therefore, there is a growing consensus that waste discharge from aquaculture operations should be reduced to minimize the negative impact on the environment, comply with regulations, and limit the so called selfpollution. ${ }^{2,3)}$ Since feed is the major source of waste in aquaculture, the management of aquaculture wastes should be approached through diet formulation, revision of feeding regimes for specific farming conditions, and improvement of feed utilization.

In this context, the total nitrogen $(\mathrm{N})$ loading onto the surrounding water from carp culture could be successfully reduced by optimizing dietary protein to energy ratio., ${ }^{4,5}$ Until recently in Japan, commercial carp diets generally contained crude protein above $40 \%$ due to the stipulation of the Agricultural Official Standard which specifies that crude protein content in carp diets must be higher than $39 \%$. 9 This type of diet usually releases 53-71 and 20-23 $\mathrm{kg}$ of total $\mathrm{N}$ and $\mathrm{P}$ per ton carp production. The value for $\mathrm{N}$ discharge $(\mathrm{T}-\mathrm{N})$ was effectively reduced to around 32 $\mathrm{kg} / \mathrm{t}$ carp production by optimizing the digestible protein/ digestible energy to $16 \mathrm{~g} / \mathrm{MJ}$. ${ }^{\circ}$ The T-P was also reduced to $18 \mathrm{~kg} / \mathrm{t}$ carp production by replacing fish meal with alternative protein sources. ${ }^{4,5)}$ Also in rainbow trout both $\mathrm{T}$ $\mathrm{N}$ and T-P together with feed conversion ratio were effectively reduced through improved feed formulation in terms of elevation of dietary energy levels. ${ }^{7}$

It is generally agreed that the tendency to overuse fish meal in fish feeds, rather than including both animal and plant protein ingredients, results in higher $\mathbf{N}$ and $\mathbf{P}$ excretions into the water system, particularly $P$ in the case of carp which have no stomachs. The absorption rate of $\mathrm{P}$ contained in fish meal, mainly in the form of tri-calcium phosphate, is extremely low in carp due to the absence of gastric juice. ${ }^{8,9)}$ As mentioned above, environmental $P$ loading from carp fed commercial diets was reported to be around $20 \mathrm{~kg} / \mathrm{t}$ of fish production on average in the case of cage culture at Lake Kasumigaura until the prefectural government established a new regulation in 1987 that the protein content of commercial carp diets to be used in the lake must be less than $37 \%$, later replaced by $36 \%$, based on the data by Watanabe et al. ${ }^{4-6)}$ The $\mathrm{N}$ excretion was successfully reduced by the improved feed formulations, however, $\mathrm{P}$ discharge from carp is still quite higher than that from other fish species like salmonids which yield output of less than $3 \mathrm{~kg}$ per ton of fish production, ${ }^{10)}$ even though the availability of $\mathrm{P}$ in the form of tri-calcium phosphate in fish meal is significantly lower in carp than salmonids. Therefore, efforts are now needed to reduce the $P$ loading from carp culture through improvement of diet formulation.

The aim of this study is to minimize the output of $P$ from carp culture in Lake Kasumigaura of Ibaragi Prefecture by improving feed formulation. As a first step, experiments were conducted to clarify current values of environmental P loading onto the lake from carp culture due to feeding of commercial diets. For this purpose six commer- 
cial carp diets used in the lake during 1996 were fed to juvenile carp to determine the rate of absorption and retention of dietary $\mathbf{P}$. Water extractable $\mathbf{P}$ in the diets which is known to be assimilated by carp $^{8)}$ was also measured for the calculation of total $P$ output.

\section{Materials and Methods}

\section{Experimental Diets}

Six commercial carp diets (A, B, C, D, E, and F) practically used for carp production during 1996 in Lake Kasumigaura, Ibaragi Prefecture, Japan, were re-prepared to the experimental diets. The proximate compositions of the diets, the values indicated in the feed bags by feed manufacturers is shown in Table 1 . The crude protein content ranged between 32.4 and $36.6 \%$, being within the range of the value regulated by the Ibaragi Prefectural Government. ${ }^{6}$ The $P$ content was $1.1-2.3 \%$, largely different among the commercial diets. The content of crude lipid, ash, and moisture also varied among the diets. These commercial diets were completely crushed to powder, added with $1 \%$ chromium oxide mixture (dextrin : chromium oxide $=1: 1$ ) as an indicator and $5 \%$ of $\alpha$-starch as a binder, and re-prepared to dry pellets as the experimental diets for the determination of absorption and retention of dietary $P$. The proximate composition of the experimental diets shown in Table 2 was slightly different from the original diets (Table 1) due to the addition of $\alpha$-starch and difference of moisture content. The gross energy content was $4.3-4.6 \mathrm{kcal} / \mathrm{g}$ diet, and the digestible energy value would be around $3.4 \mathrm{kcal} / \mathrm{g}$ diet which clears the regulation value if the absorption rate of energy was supposed to be $80 \%$.

The method of diet preparation was the same as that reported previously. ${ }^{11,12)}$

\section{Feeding Experiment}

Juvenile common carp Cyprinus carpio purchased from Sankyo Suisan Co. Ltd. were reared in $60 \mathrm{l}$ glass tanks with a commercial carp diet for about 5 months. Then the fish having an average body weight of $12.4 \pm 0.4 \mathrm{~g}$ were randomly distributed into twelve $60 /$ glass tanks, 25 fish each (6 lots, duplicate) whilst another 25 fish were sampled and pooled from the remaining fish for initial whole body proximate analysis. They were fed the experimental diets with chromium oxide for four weeks, 3 times per day, 6 days a week, each to near satiation at water temperature of 23.0$25.0^{\circ} \mathrm{C}$ for the determination of the rate of absorption and retention of dietary $P$. Collection of feces from each tank was started at the $5^{\text {th }}$ day after the initiation of feeding, and continued for several days until enough samples were obtained for the determination of $\mathrm{P}$ content in the feces. ${ }^{11}$ The pooled feces were dried in a vacuum dryer to prepare analytical samples. At the end of the experiment 10 fish were pooled from each lot after begin starved for one day,

Table 1. Proximate composition and phosphorus contents of the commercial diets ${ }^{* 1}$

\begin{tabular}{|c|c|c|c|c|c|c|}
\hline \multirow{2}{*}{$\begin{array}{l}\text { Proximate } \\
\text { composition }(\%)^{*_{2}}\end{array}$} & \multicolumn{6}{|c|}{ Diets } \\
\hline & A & $\mathrm{B}$ & $\mathrm{C}$ & $\mathrm{D}$ & $\mathrm{E}$ & $\mathbf{F}$ \\
\hline Moisture & 9.2 & 10.0 & 10.4 & 8.6 & 9.1 & 8.2 \\
\hline Crude protein & 34.1 & 36.6 & 34.6 & 34.9 & 32.4 & 34.8 \\
\hline Crude lipid & 8.6 & 5.8 & 7.2 & 11.3 & 6.7 & 9.4 \\
\hline Crude ash & 11.0 & 10.1 & 9.7 & 10.0 & 8.3 & 7.1 \\
\hline \multicolumn{7}{|c|}{ Dry matter weight basis $(\mathrm{g} / \mathrm{l} 00 \mathrm{~g}$ diet) } \\
\hline Crude protein & 37.6 & 40.6 & 38.7 & 38.2 & 35.7 & 37.8 \\
\hline Crude lipid & 9.5 & 6.5 & 8.0 & 12.3 & 7.3 & 10.2 \\
\hline Crude ash & 12.1 & 11.2 & 10.9 & 10.9 & 9.2 & 7.7 \\
\hline Phosphorus (\%) & 2.3 & 1.6 & 1.9 & 1.8 & 1.4 & 1.1 \\
\hline
\end{tabular}

*Used in Lake Kasumigaura during 1996.

${ }^{*}$ Commercial values indicated on the feed bags.

Table 2. Nutrient contents of the experimental diets

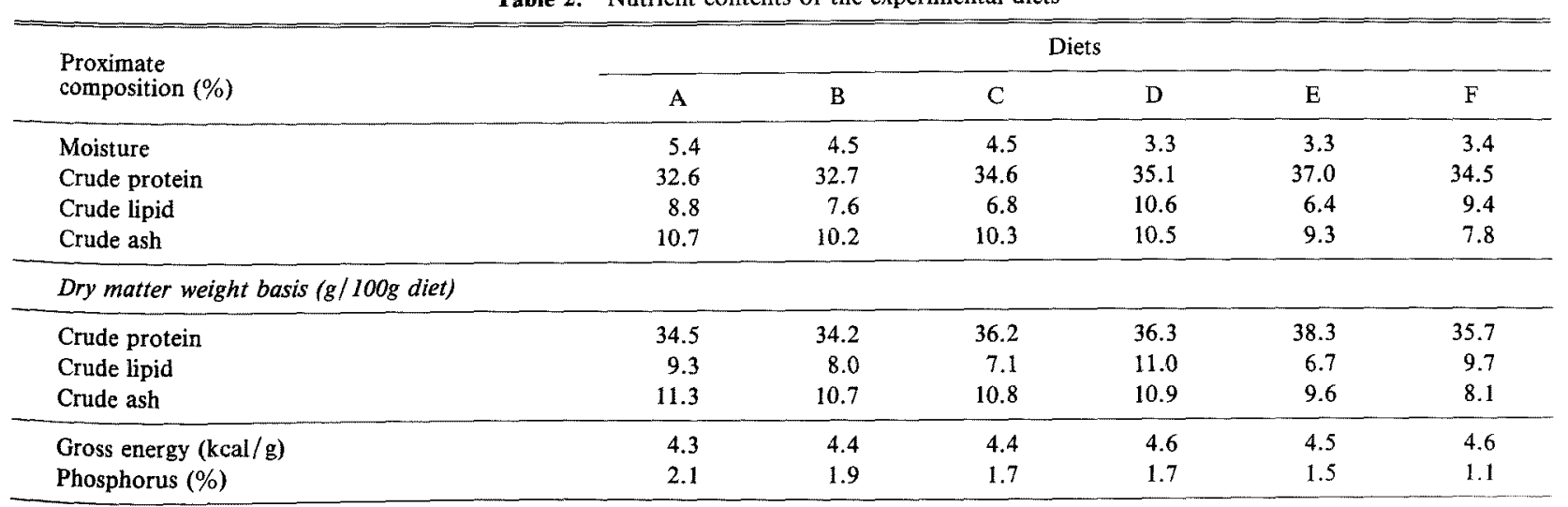


anesthetized with ethylene glycol monophenyl ether (300 ppm), weighed individually, and stored at $-20^{\circ} \mathrm{C}$ until whole body analysis.

Other details of feeding and fish care were the same as those described previously. ${ }^{11,12)}$

\section{Analytical Methods}

In this study the total $P$ output from carp culture was calculated based on feed gain ratio and availability to carp of dietary $\mathbf{P}$ which was estimated by the amount of $\mathbf{P}$ extracted with deionized water, ${ }^{8,13,14)}$ absorption rate by the indirect method, and $P$ retention in whole body of carp. The methods for analysis of $P$ in the diets and feces and calculation of the apparent $P$ digestibility and retention rate of dietary $\mathbf{P}$ together with proximate analysis and measurement of gross energy by a bomb calorimeter were the same as those described previously. ${ }^{12,15-17)}$

\section{Statistical Analysis}

For statistical comparisons data were assessed for the different treatments by analysis of variance (ANOVA). Differences among means were considered significant at $P<0.05$. Post hoc analyses were performed using Scheffes test $(P<0.05)$ to resolve the differences among means of duplicate groups.

\section{Results and Discussion}

\section{Water Extractable $P$ in Diets}

The amount of $P$ extractable with deionized water is already reported to be almost equal to that absorbed by carp ${ }^{8)}$ As shown in Table 3, the water extractable $\mathrm{P}$ content of the experimental diets was $25.9-35.8 \%$ of total dietary $\mathrm{P}$ and largely fluctuated among the diets as observed in the total $P$ content in the commercial diets. Furthermore, there was no correlation between the water extractable and total $\mathrm{P}$ in the diets. The available $\mathrm{P}$ contents ranged between 0.29 to $0.75 \%$, only diets $A$ and $D$ were satisfying the $P$ requirement of carp $(0.6-0.7 \%){ }^{8,9)}$ These values would be reflecting the feed performances and $\mathrm{N}$ and $\mathrm{P}$ discharges as described later.

\section{Absorption Rate of Dietary $P$}

The absorption rate of dietary $\mathrm{P}$ determined by the indirect method is shown in Table 3 . The values ranged from 26.9 to $37.3 \%$ and coincided well with those determined by the water extraction method in the same diets. These data confirmed the previous result that digestibility of dietary $\mathrm{P}$ in carp can be estimated from the amount of $\mathrm{P}$ ex- tracted from the diet by deionized water, namely, availability to carp of various $P$ compounds depends on their water solubility ${ }^{8)}$ Therefore, in the case of carp the water extraction method could be employed as a simple method for the estimation of the available $P$ content in the diet. The difference of absorption rate among the commercial diets might have resulted from the difference of $P$ compounds supplemented in the diets in terms of mono- or di-basic $P$.

\section{Retention Rate of Dietary P in Whole Body of Carp}

The retention rate of $P$ in the whole body of carp fed the experimental diets for four weeks is shown in Table 3. The rate of retention ranged between 20.3 and $34.2 \%$ among the diets, generally lower than those determined by the water extraction and digestibility methods. Comparison between these values suggested that $63-93 \%$ of absorbed $P$ was retained in the fish body and the other parts might be excreted again into the digestive tract as observed in mammals or excreted through gills and urine. ${ }^{18,19)}$ However, there seems to be a positive relationship between the increased rates of $\mathbf{P}$ absorption and its retention among the diet groups. Further experiments will be needed to clarify the destiny of absorbed $\mathrm{P}$ in fish. However, absorbed dietary $P$ which was not retained in the fish could be regarded as excreted into water body, therefore, the $\mathrm{P}$ retention value should be employed in the calculation of environmental $\mathrm{P}$ loading from carp. In fact, the balance between total amount of $P$ given to fish and the amount of $P$ retained in fish body is used for the estimation of $P$ output.

\section{Feed Performances}

The feed performances in fish fed the test diets for four weeks are shown in Table 4. Even after only four weeks of feeding, a difference in growth performances among the dietary treatments was seen, therefore, if the period were longer it would be more clear. Growth rate of fish was largely different between the dietary treatments as was expected from the available $P$ levels in the diets and the lowest value of $76.5 \%$ was recorded in the fish fed diet $F$ containing the lowest amount of available P $(0.29 \%)$, while it was 127.0 and $146.1 \%$ in fish fed diets $\mathrm{A}$ and $\mathrm{D}$ respectively, both containing enough available $P$ to satisfy the carp requirement. Feed gain ratio was less than 1.4 in all groups and also superior in fish fed diets $A$ and $D$, being 0.92 and 0.83 respectively. Daily feed consumption rate was approximately similar (about 3\% of fish body weight) among all groups. Protein efficiency ratios (PER) of 3.3 and 3.5, higher than other groups, were again obtained in fish fed

Table 3. Available $P$ contents of the experimental diets measured based on water extraction and the rate of absorption and $P$ retention in whole body of carp during 4 weeks feeding

\begin{tabular}{|c|c|c|c|c|c|c|}
\hline \multirow{2}{*}{$\begin{array}{l}\text { Diet } \\
\text { groups }\end{array}$} & \multicolumn{2}{|c|}{ Water extraction } & \multicolumn{2}{|c|}{ Absorption } & \multicolumn{2}{|c|}{ Retention } \\
\hline & $\begin{array}{l}\% \text { of total } \\
\text { dietary } \mathrm{P}\end{array}$ & $\begin{array}{c}\text { Available P } \\
(\%)\end{array}$ & $\begin{array}{l}\% \text { of total } \\
\text { dietary } \mathrm{P}\end{array}$ & $\begin{array}{c}\text { Available } P \\
(\%)\end{array}$ & $\begin{array}{l}\% \text { of total } \\
\text { dietary } \mathrm{P}\end{array}$ & $\begin{array}{c}\% \text { of } \\
\text { absorbed } \mathrm{P}\end{array}$ \\
\hline A & 35.8 & 0.75 & 37.3 & 0.78 & 25.9 & 69.4 \\
\hline B & 30.0 & 0.56 & 31.5 & 0.61 & 20.3 & 64.4 \\
\hline $\mathrm{C}$ & 25.9 & 0.45 & 26.9 & 0.47 & 21.7 & 80.7 \\
\hline D & 35.1 & 0.59 & 36.7 & 0.62 & 34.2 & 93.2 \\
\hline $\mathrm{E}$ & 28.5 & 0.42 & 30.8 & 0.45 & 22.2 & 72.1 \\
\hline $\mathbf{F}$ & 27.1 & 0.29 & 32.5 & 0.35 & 20.4 & 62.8 \\
\hline
\end{tabular}


Table 4. Feeding performances of carp fed the experimental diets for 4 weeks

\begin{tabular}{|c|c|c|c|c|c|c|}
\hline & \multicolumn{6}{|c|}{ Diet groups } \\
\hline & A & $\mathbf{B}$ & C & $\mathrm{D}$ & $\mathrm{E}$ & $\mathrm{F}$ \\
\hline No. of fish & 25 & 25 & 25 & 25 & 25 & 25 \\
\hline Initial body weighy (g) & 12.8 & 12.6 & 12.3 & 12.7 & 12.5 & 12.9 \\
\hline Final body weight $(\mathrm{g})^{*}$ & $29.1^{\mathrm{ab}}$ & $23.6^{\mathrm{b}}$ & $24.1^{b}$ & $31.4^{\mathrm{a}}$ & $25.4^{b c}$ & $22.7^{\circ}$ \\
\hline Growth rate $(\%)^{*}$ & $127.0^{\mathrm{ab}}$ & $87.1^{\mathrm{c}}$ & $96.7 \mathrm{bc}$ & $146.1^{\mathrm{a}}$ & $103.7^{b c}$ & $76.5^{\circ}$ \\
\hline Feed gain ratio* & $0.92^{\text {bc }}$ & $1.22^{\mathrm{ab}}$ & $1.23^{\mathrm{ab}}$ & $0.83^{\mathrm{c}}$ & $1.05^{b c}$ & $1.26^{\mathrm{a}}$ \\
\hline Protein efficiency ratio* & $3.3^{\mathrm{a}}$ & $2.5^{\mathrm{b}}$ & $2.4^{\mathrm{b}}$ & $3.5^{\mathrm{a}}$ & $2.6^{\mathrm{b}}$ & $2.3^{\mathrm{b}}$ \\
\hline
\end{tabular}

*Values within the same row, not sharing common superscript letters are significantly different at $P<0.05$.

Table 5. Proximate composition and phosphorus contents in whole body of carp fed the experimental diets for 4 weeks

\begin{tabular}{|c|c|c|c|c|c|c|c|}
\hline \multirow{2}{*}{$\begin{array}{c}\text { Proximate } \\
\text { composition }(\%)\end{array}$} & \multicolumn{7}{|c|}{ Diet groups } \\
\hline & Initial & A & B & $\mathrm{C}$ & $\mathbf{D}$ & $\mathbf{E}$ & $\mathrm{F}$ \\
\hline Moisture* & 79.2 & $78.4^{\mathrm{ab}}$ & $79.0^{\mathrm{a}}$ & $78.1^{\mathrm{ab}}$ & $77.4^{\mathrm{ab}}$ & $76.5^{\mathrm{ab}}$ & $75.5^{\mathrm{b}}$ \\
\hline Crude protein* & 14.1 & $14.5^{\mathrm{bc}}$ & $14.4^{c}$ & $15.0^{\mathrm{ab}}$ & $15.4^{\mathrm{ab}}$ & $15.4^{a}$ & $15.2^{\mathrm{ab}}$ \\
\hline Crude lipid ${ }^{*}$ & 3.2 & $4.2^{b}$ & $3.8^{b}$ & $4.5^{b}$ & $4.1^{\mathrm{b}}$ & $5.3^{\mathrm{b}}$ & $7.1^{\mathrm{a}}$ \\
\hline Crude ash & 2.7 & 2.6 & 2.4 & 2.3 & 2.3 & 2.4 & 2.2 \\
\hline Phosphorus ${ }^{*}(\%)$ & 0.48 & $0.49^{a}$ & $0.47^{\mathrm{a}}$ & $0.47^{a}$ & $0.48^{\mathrm{a}}$ & $0.41^{\mathrm{ab}}$ & $0.39^{\mathrm{b}}$ \\
\hline
\end{tabular}

*Values within the same row, not sharing common superscript letters are significantly different at $P<0.05$.

these diets, suggesting that crude protein in diets $A$ and $D$ was efficiently utilized, while lower PER of $2.4-2.6$ in other groups indicated lower protein utilization, leading to higher $\mathrm{N}$ excretion. ${ }^{4-6}$ ) These results have shown that the quality of current commercial diets which are being used for carp production in Lake Kasumigaura largely fluctuated among the feed manufacturers.

\section{Proximate Composition and P Content of Fish Whole Body}

Analytical data on whole body of carp at the end of the four week feeding is shown in Table 5. Only slight differences were recorded for the crude protein (14.5-15.4\%) and the body ash contents were similar for all the groups. The lipid content was high in the fish fed diets $E$ and $F$ with lower levels of available $P$, especially in the fish fed diet $\mathrm{F}(7.1 \%)$, significantly higher $(P<0.05)$ than other groups. The increased lipid levels in whole body is one of the typical symptoms of $\mathbf{P}$ deficiency in carp. ${ }^{20)}$ The higher lipid content reflected lower moisture content in these groups.

The $\mathrm{P}$ contents in whole body of the fish were slightly lower in the fish fed the $\mathrm{P}$ deficient diets $\mathrm{E}$ and $\mathrm{F}$.

\section{Estimation of Environmental P Loading from Carp Cul-} ture

The T-P ( $\mathrm{kg} / \mathrm{t}$ fish production) calculated based on feed gain ratio ${ }^{4-6)}$ of each diet and the amount of available $P$ in diets measured by the water extraction method, digestibility study, and $P$ retention rate are shown in Table 6 . The $T$ $P$ calculated based on water extractable $P$ was 9.1-16.8 (12.5 on average) and the value based on $P$ absorption rate was 9.1-16.2 (12.1 on average), both values coincided well in the same diets as already expected from the content of available $P$ determined by both the methods. The T-P based on $P$ retention was $9.1-18.8$ (13.6 on average),
Table 6. Total phosphorus loading onto the water environment calculated based on the values of $\mathbf{P}$ extracted with deionized water, absorbed and retained in carp*

\begin{tabular}{cccc}
\hline \multirow{2}{*}{$\begin{array}{c}\text { Diet } \\
\text { groups }\end{array}$} & \multicolumn{3}{c}{ Total phosphorus loading $(\mathrm{kg} / \mathrm{t}$ carp production) based on } \\
\cline { 2 - 4 } & Water extractable P & P absorption & P retention \\
\hline A & 12.4 & 12.1 & 14.3 \\
B & 16.8 & 16.2 & 18.8 \\
C & 15.8 & 15.6 & 16.7 \\
D & 9.0 & 8.8 & 9.1 \\
E & 11.0 & 10.7 & 12.0 \\
F & 9.8 & 9.1 & 10.7 \\
\hline
\end{tabular}

*Date shows the average values of duplicate groups.

about $10 \%$ higher than the former values. As mentioned above, this difference might be originated from a loss of $a b$ sorbed $\mathrm{P}$ through renal or gill excretion. ${ }^{18,19,21-24)}$ As mentioned earlier, the difference between the total amount of $P$ given to fish and the amount of $P$ retained in fish body can be regarded as T-P onto the environment. Therefore, the rate of $P$ retention should be employed in the practical estimation of T-P from carp culture operation as already reported previously in the case of total $N$ discharge. ${ }^{4-6)}$ The higher growth performances reflected lower T-P as was observed in the fish fed the diet D. Kim et al. ${ }^{25)}$ also observed a maximum growth and a minimum $\mathrm{P}$ discharge from juvenile common carp fed diets containing the required amount of available $P$ whilst a $P$ deficient diet resulted in lower growth and higher T-P.

The present data have shown that the T-P from carp culture in Lake Kasumigaura was 9.1-18.8 (13.6 on average), largely variable between the commercial diets. Therefore, the data on the total consumption of each commercial feed per annum would be needed for the calculation of actual 
$\mathrm{T}$-P in the lake. The feed gain ratio of commercial diets used in this experiment was $0.83-1.26$ (1.09 on average), lower than the value used for calculation of T-P in the lake by the prefectural government. The T-P was reported to be 12.3 by the Ibaragi Prefectural Institute of Inland Fisheries when calculated based on the feed gain ratio of 1.4 and the available $P$ content in the commercial diets. ${ }^{* 1}$ The $T-P$ in this study will increase from the average value of 13.6 to 18.1 , if calculated based on feed gain ratio of 1.4 , average total $\mathrm{P}$ in diets of $1.7 \%$, and average $\mathrm{P}$ retention of $24 \%$. The difference of feed gain ratio would be originated from the difference of feed loss between feeding in aquaria and net cages. Further experiments will be required to obtain more clear picture of current status of T$P$ from carp culture in Lake Kasumigaura.

\section{References}

1) G. Persson: Eutrophication resulting from salmonid fish culture in fresh and salt waters: Scandinavian experiences, in "Nutritional Strategies \& Aquaculture Waste", Proceedings of the First International Symposium on Nutritional Strategies in Management of Aquaculture Waste, 5-8 June 1990, (ed. by C. B. Cowey and C. Y. Cho), Guelph, Ontario, Canada, 1991, pp. 163-185.

2) R. J. Gowen and N. B. Bradbury: The ecological impact of salmonid farming in coastal waters, a review. Oceanogr. Mar. Biol. Ann. Rev., 25, 563-575 (1987).

3) C. Folke and N. Kautsky: The role of ecosystems for a sustainable development of aquaculture. Ambio, 18, 234-243. (1989).

4) T. Watanabe, T. Takeuchi, S. Satoh, K. Wang, T. Ida, M. Yaguchi, M. Nakada, T. Amano, S. Yoshijima, and H. Aoe: Development of practical carp for reduction of total nitrogen loading on water environment. Nippon Suisan Gakkaishi, 53, 2217-2225 (1987).

5) T. Watanabe, T. Takeuchi, S. Satoh, T. Ida, and M. Yaguchi: Development of low protein high energy diets for practical carp culture with special reference to reduction of total nitrogen excretion. Nippon Suisan Gakkaishi, 53, 1413-1423 (1987).

6) T. Watanabe: Past and present approaches to aquaculture waste management in Japan, in "Nutritional Strategies \& Aquaculture Waste", Proceedings of the First International Symposium on Nutritional Strategies in Management of Aquaculture Waste, 5-8 June 1990, (ed. by C. B. Cowey and C. Y. Cho), Guelph, Ontario, Canada, 1991, pp. 137-154.

7) S. J. Kaushik and A. De. O. Teles: Effect of digestible energy on N and energy balance in rainbow trout. Aquaculture, 50, 89-101 (1985).

8) S. Satoh, V. Voranop, T. Takeuchi, and T. Watanabe: Availability of phosphorus in various phosphates to carp and rainbow trout determined by a simple fractionation method. Fisheries Sci., 63, 297300 (1997).

9) C. Ogino, L. Takeuchi, H. Takeda, and T. Watanabe: Availability of dietary phosphorus in carp and rainbow trout. Nippon Suisan Gakkaishi, 45, 1527-1532 (1979).
10) H. G. Ketola: Mineral nutrition. Effects of phosphorus in trout and salmon feeds on pollution, in "Nutrition and feeding in fish", (ed. by C. B. Cowey, A. M. Mackie and C.B. Bell), Academic Press, New York, pp. 465-474 (1985).

11) C. Ogino and H. Takeda: Mineral requirements in fish-III. Calcium and phosphorus requirements in carp. Nippon Suisan Gakkaishi, 42, 793-799 (1976).

12) T. Takeuchi, T. Watanabe, S. Satoh, R. C. Martino, T, Ida, and M. Yaguchi: Suitable levels of protein and digestible energy in practical carp diets. Nippon Suisan Gakkaishi, 55, 521-527 (1989).

13) I. B. Ferguson, N. A. Turner, and E. G. Bollard: Problems in fractionating calcium in plant tissue. J. Sci. Food Agic., 31, 7-14 (1980).

14) Y. Shimma: Mineral evaluation, in "Codification of feed quality evaluation methods for establishment of aquaculture feeding standards", Agriculture, Forestry and Fisheries Research Council Secretariat, 1989 , pp. 28-37.

15) A. Furukawa and H. Tsukahara: On the acid digestion method for determination of chromic oxide as an index substance in study of digestibility in fish feed. Nippon Suisan Gakkaishi, 32, 502-506 (1966).

16) J. Folch, M. Lees, and G. H. S. Stanley: A simple method for the isolation and purification of total lipid from animal tissues. J. Biol. Chem., 226, 497-509 (1957).

17) H. H. Tausky and E. Shorr: A microcolorimetric method for the determination of inorganic phosphorus. J. Biol. Chem., 202, 675-685 (1953).

18) S. P. Lall: Digestibility, metabolism and excretion of dietary phosphorus in fish. Nutritional strategies and aquaculture waste, in "Nutritional Strategies \& Aquaculture Waste", Proceedings of the First International Symposium on Nutritional Strategies in Management of Aquaculture Waste, 5-8 June 1990, (ed. by C. B. Cowey and C. Y. Cho), Guelph, Ontario, Canada, 1991, pp. 21-35.

19) I. J. Chester, D. K. O. Chan, and J. C. Rankin: Renal function in the European eel (Anguilla anguilla L.). Effect of caudal neurosecretory system, corpuscles of Stannius, neurohypophysial peptides and vasoactive substances. $J$. Endocrinol., 43, 21-31 (1969).

20) M. Takeuchi and J. Nakazoe: Effect of dietary phosphorus on lipid content and its composition in carp. Nippon Suisan Gakkaishi, 47, 347-352 (1981).

21) D. Weismann, H. Scheid, and E. Pfeffer: Water pollution with phosphorus of dietary origin by intensively fed rainbow trout, Salmo gairdneri Rich. Aquaculture, 69, 263-270 (1988).

22) T. Takeuchi: Digestion and nutrition in "Fish Physiology" (ed. by Y. Itazawa and Y. Hanyu), Koseisha-Koseikaku, Tokyo, pp. 67101.

23) G. Persson: Relationships between feed, productivity and pollution in the farming of large rainbow trout (Salmo gairdneri). Swedish Environmental Protection Agency, Stockholm, PM3534, 1988, pp. 48.

24) G. R. Roberto and H. H. Grahame: Phosphorus fractionation and mobility in the food and feces of hatchery reared rainbow trout ( $\mathrm{On}$ chorhynchus mykiss). Aquaculture, 145, 183-193 (1996).

25) J. D. Kim, K. S. Kim, J. S. Song, J. Y. Lee, and K. S. Jeong: Optimum level of dietary monocalcium phosphate based on growth and phosphorus excretion of mirror carp, Cyprinus carpio. Aquaculture, 161, 337-344 (1998).

\footnotetext{
${ }^{*_{1}}$ Fisheries Science of Kasumigaura, Ibaragi Prefectural Institute of Inland Fisheries, Ibaragi, Japan, 1995, p. 1-16.
} 